\title{
Solvent-free Microwave-Assisted Ortho-Alkylation of Aromatic Ketimine with Acrylic Acid Derivatives by Rh(I) Catalyst ${ }^{\dagger}$
}

\author{
Eun-Ae Jo, Jeong-Ae Ahn, and Chul-Ho Jun* \\ Department of Chemistry and Center for Bioactive Molecular Hybrid, Yonsei University, Seoul 120-749, Korea \\ "E-mail: junch@yonseiac.kr \\ Received Jine 14, 2007
}

\begin{abstract}
Microwave(MW)-assisted ortho-alkylation of aromatic imine with acrylic acid derivatives was performed in the presence of a $\left(\mathrm{PPh}_{j}\right)_{3} \mathrm{RhCl}$ catalyst, and corresponding ortho-alkylated ketones were obtained after hydrolysis of the resulting ketimines. This solventless MW-assisted ortho-alkylation was highly efficient compared with conventional heating probably due to the specific MW effect.
\end{abstract}

Key Words : Ortho-alkylation, Microwave, Rhodium, Homogeneous catalyst, Ketimine

\section{Introduction}

Catalytically selective activation of organic molecules by transition metal catalysts is a current interest in organic synthesis' because this strategy may allow the avoidance of environmental problems such as waste formation that can occur in industrial synthesis. An interesting example of selective $\mathrm{C}-\mathrm{H}$ bond activation is Ru-catalyzed orthoalkylation of aromatic ketone, known as Murai's reaction. ${ }^{2}$ One drawback of this reaction is the limited usefulness of olefin substrates, due to the difficulty of applying olefins bearing a functional group. To overcome this limitation, a new procedure using a ketimine of aromatic ketone with $\mathrm{Rh}(\mathrm{I})$ catalyst was developed for ortho-alkylation and orthoalkenylation. ${ }^{3}$ Since this strategy using ketimine tolerates various functional groups of olefin substrates, functionalized olefins can be successfully applied to the ortho-alkylation of aromatic ketimine, ${ }^{4}$ in which vigorous reaction conditions are required to initiate the reaction. Recently, much interest has been shown in microwave-assisted reactions to facilitate transition metal catalyzed reactions. It is especially environmentally benign since the reaction can be carried out without solvent. Therefore, we are intrigued by the use of MWassisted reactions under solvent-free conditions in orthoalkylation reaction. Among many unsaturated substrates, acryl amide and acrylic ester exhibited high reactivity in MW-assisted ontho-alkylation compared to conventional heating. In this paper, we report on the solventless orthoalkylation of aromatic ketimine with acrylic acid derivatives under microwave irradiation.

When the reaction of benzylimine 1a and dimethyl acrylamide (2a) was carried out in the presence of $\left(\mathrm{PPh}_{3}\right)_{3} \mathrm{RhCl}$ (3) at $150^{\circ} \mathrm{C}$ for $5 \mathrm{~min}$ under microwave irradiation $(25$ watt), ortho-alkylated acetophenone 4 a was obtained in a $90 \%$ isolated yield after hydrolysis of the resulting ketimine (Table 1, entry 1 ).

However, when the identical reaction was applied by

${ }^{\top}$ This paper is dedicated to Professor Sang Chul Shim on the occasion of his honorable retirement.
Table 1. Comparison between the reactivity of acryl amide and that of $t$-butylethylene toward ortho-alkylation under thermal and MWirradiated conditions

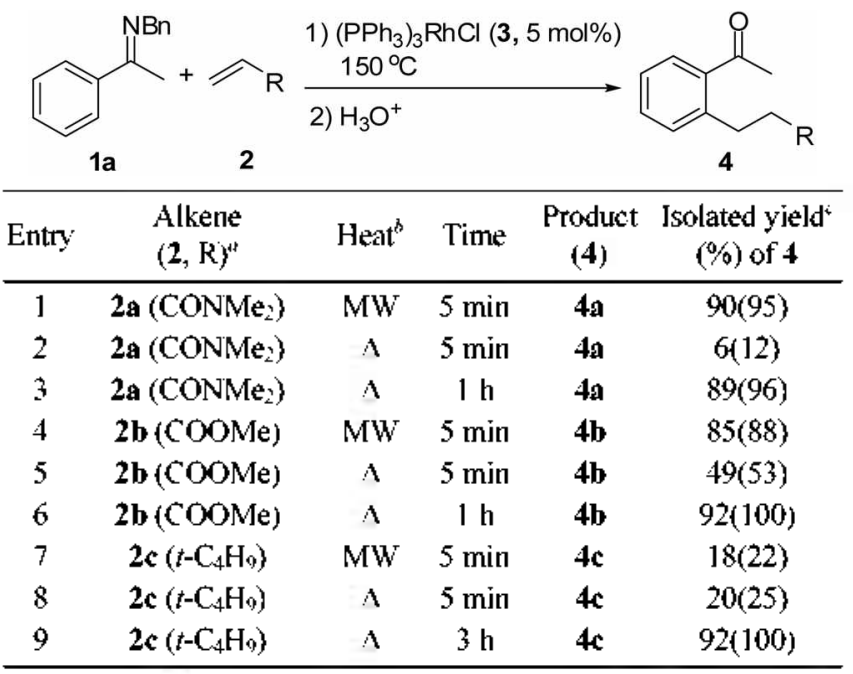

"1.2 eq. of olefin wias used. 'Microwave (MW) or oil bath under similar conditions $(\Delta)$. Tsolated yields. GC yield of 4 given in the parentheses.

conventional thermal heating at $150{ }^{\circ} \mathrm{C}$ for $5 \mathrm{~min}$, only $6 \%$ yield of $4 \mathrm{a}$ was isolated, and extended reaction time to $1 \mathrm{~h}$ afforded $4 \mathbf{a}$ in a $89 \%$ yield (entries 2 and 3 ). This dramatic difference between the reactivity under $\mathrm{MW}$ and that of conventional heating reveals an important specific microwave effect. In the reaction of $\mathbf{1 a}$ and acrylic ester ( $\mathbf{2 b}$ ) under identical reaction conditions, corresponding ortho-alkylated ketone $4 \mathrm{~b}$ was isolated in a $85 \%$ yield under MW irradiation and a $49 \%$ yield for thermal heating, respectively (entries 4 and 5). Although the yield difference was not marginal between MW and thermal heating compared with the reaction of $2 \mathbf{a}$, a certain difference could still be observed in this reaction. For comparison with these functionalized olefins, the reaction of $t$-butylethylene (2c) with 1 a was performed at $150^{\circ} \mathrm{C}$ for $5 \mathrm{~min}$ under $\mathrm{MW}$ irradiation to afford only $18 \%$ isolated yield of $\mathbf{4 c}$, while the reaction with conventional heating produced a $20 \%$ isolated yield of $\mathbf{4 c}$, and the reaction was completed in 3h (entries 7-9). Among 
Table 2. Rh(I)-Catalyzed oriho-Alkylation of Aromatıc Ketımıne la with acryl amide $2 \mathbf{a}^{a}$

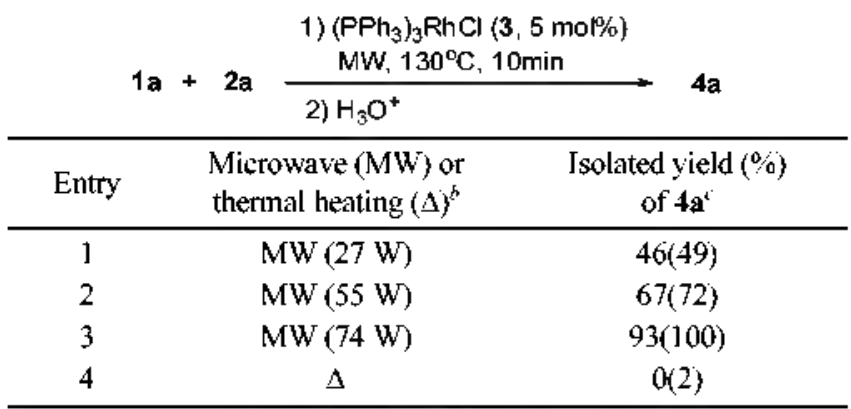

Teaction conditions: $3(0.015 \mathrm{mmol}), 1 \mathrm{a}(0.3 \mathrm{mmol}), 1.2$ equiv. of $2 \mathrm{a}$ mixture at $130{ }^{\circ} \mathrm{C}$ for $10 \mathrm{~min}$. 'The power (walts) of $\mathrm{MW}$ can be controlled by adjusting the pressure of air blowing. 'Tsolated yields. GC yield of 4 given in the parentheses.

the olefins tested, acryl amide $\mathbf{2} \mathbf{a}$ and ester $\mathbf{2 b}$ showed much higher reactivity than $t$-butylethylene (2c). The $\mathrm{MW}$ reaction of acrylamide 2 a especially showed a fairly high enhancement of reactivity compared with the thermal reaction.

From these results, we can infer an important specific MW effect with $\mathbf{2 a}$, which leads to the increased yield of the product as MW power increases. ${ }^{6}$ When the reaction of 1a and $2 \mathrm{a}$ was carried out at $130^{\circ} \mathrm{C}$ for $10 \mathrm{~min}$ with moderate MW power ( 27 watt), $46 \%$ isolated yield of $4 a$ was obtained. In comparison, isolation yjelds of $67 \%$ and $93 \%$ for $4 a$ were obtained with high powered MW of 55 and 74 watts respectively, under the same reaction temperature and time in the presence of same catalyst (Table 2, entries 2 and 3 ). These high powered MWs could be obtained by blowing an air with a certain amount of pressure to the reaction vessel to maintain the temperature $\left(130^{\circ} \mathrm{C}\right)$ of the reaction mixture (Figure 1).

The reaction mechanism is shown in Scheme 1 . The Rh(I) complex 3 reacts with the ortho- $\mathrm{C}-\mathrm{H}$ bond in the phenyl group of 1a to generate a 5-membered ring metallacycle intemnediate 5a. Subsequent hydride-insertion into 2a affords 6a. Reductive elimination of 6 a leads to the orthoalkylated ketimine $\mathbf{8 a}$, which is hydrolyzed by acidic water to give 4a.

A. Loupy emphasized that specific MW effect can be observed for polar mechanism when the polarity is increased during the reaction, from the ground state (GS) towards the

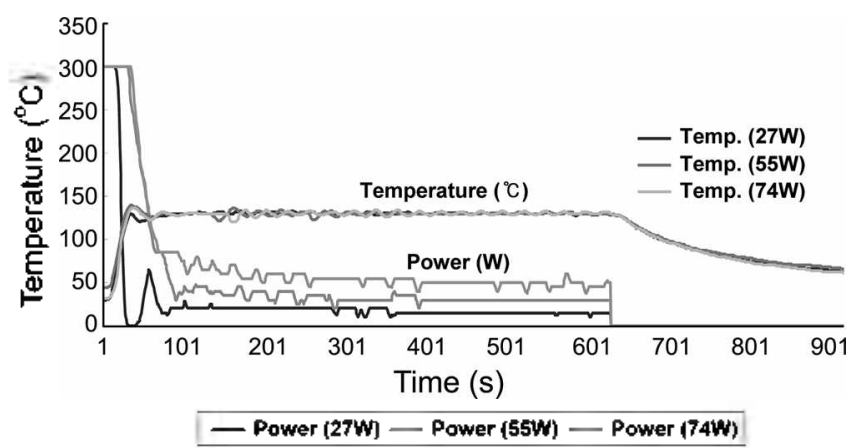

Figure 1. Reaction 1a and 2a with 3 at $130^{\circ} \mathrm{C}$ under different power of MW irradiation (normal and air cooling).

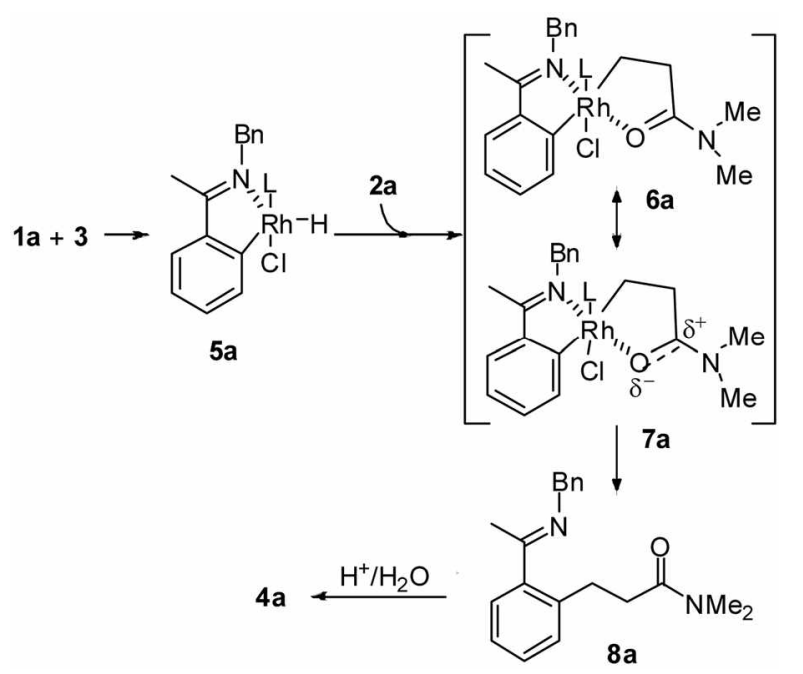

Scheme 1. Proposed Mechanism for ortho-Alkylation of Ketimine la with 2a under catalyst 3.

transition state (TS) ${ }^{6,7}$ Therefore it may be explained by the possibility that the observed high specific MW-effect in the reaction of $1 a$ and $2 a$ is due to the development of a pronounced dipole-polarized intermediate $7 \mathbf{a}$, near to the transition state, generated from $6 \mathrm{a}$. Since the dipole of the $7 \mathbf{a}$ is more pronounced than the ground state in the reaction, it results in a decreasing effect of activation enthalpy due to the enhanced dipole-dipole interactions with the electric field generated from the MW reactor when the reaction has progressed. Contrary to this result, the MW-assisted orthoalkylation of 1a with t-butylethylene (2c) did not show any dramatic rate-accelerating effect (Table 1 , entry 7), probably due to the formation of non-polarized intermediate $7 \mathbf{b}$.

Other functionalized olefins were applied in this reaction and representative examples were indicated in Table 3. When the reactivity of the aromatic ketimines having different alkyl substituents $\left(R^{\prime}\right)$ were compared, the electrondonating group, such as the methoxy group on the phenyl ring, showed a better result than the electron-withdrawing group such as the trifluoromethyl group (entries 1 and 2). The reactivity of 1d is low compared with that of 1a (entry 3 ). The cyclic tertiary amine functionality in the amide of $\mathbf{2 d}$ also resulted in a good yield of corresponding orthoalkylated product $\mathbf{4 g}$. In particular, acrylamide $2 \mathrm{e}$ bearing a secondary amine functionality showed a large acceleration rate in producing ontho-alkylated product $4 \mathrm{~h}$ since the $\mathrm{MW}$ reaction was completed in $2 \mathrm{~min}$, determined by $\mathrm{GC}$, while thermal conventional heating resulted in only a $9 \% \mathrm{GC}$ yield of product.

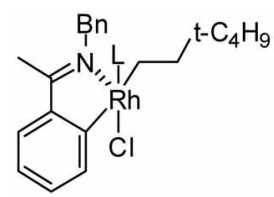

$7 \mathrm{~b}$

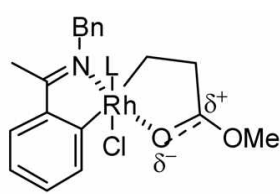

$7 c$

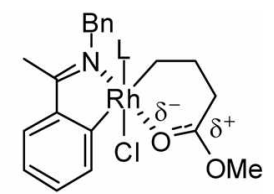

7d
Figure 2 
Table 3. Rh(T)-Catalyzed ortho-Alkylation of Aromatic Ketimine 1 with Functionalized Olefins 2

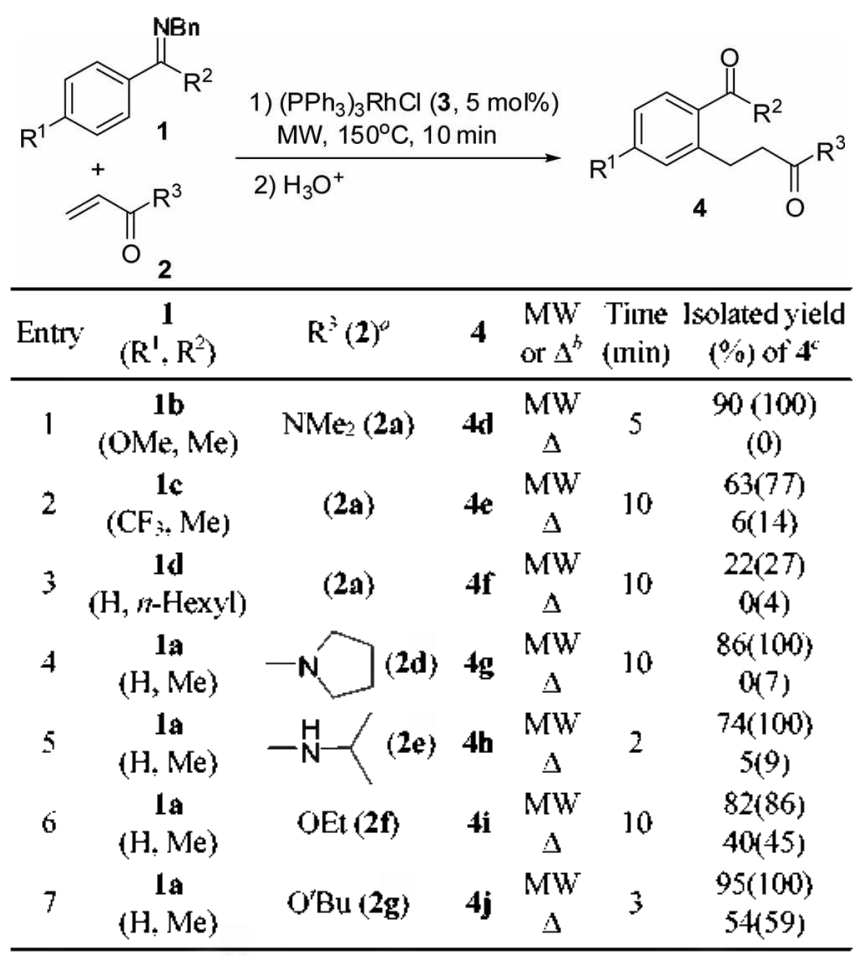

"1.2 equiv, of olefin wass used. 'Microwave (MW) or oil bath under similar conditions ( $\Delta$ ). Tsolated yields GC yield of 4 given in the parentheses.

Like $\alpha, \beta$-unsaturated amides, $\alpha, \beta$-unsaturated esters also exhibited rate enhancement under MW irradiation compared with conventional heating. For example, when the reaction was performed with ethyl acrylate (21) under MW irradiation for $10 \mathrm{~min}$, corresponding ortho-alkylated acetophenone $4 \mathbf{i}$ was isolated in $82 \%$ yield, while only $40 \%$ isolated yield of product was obtained with conventional heating (entry 6 ). In particular, with $t$-butyl acrylate $(2 \mathrm{~g})$ the reaction was completed to give $\mathbf{4 j}$ in $95 \%$ isolated yield within $3 \mathrm{~min}$ under MW conditions whereas the reaction with conventional heating afforded a $54 \%$ isolated yield of the product

Table 4. Rh(I)-catalyzed ortho-alkylation of aromatic ketimine la with unsaturated esters, $\mathbf{2 a}$ and $\mathbf{2 h}$

$$
1 \mathrm{a}+\overbrace{2} \frac{\begin{array}{l}
\text { 1) }\left(\mathrm{PPh}_{3}\right)_{3} \mathrm{RhCl}(3,5 \mathrm{~mol} \%) \\
\frac{150^{\circ} \mathrm{C}, 5 \mathrm{~min}}{2} \mathrm{H}_{3} \mathrm{O}^{+}
\end{array}}{4}
$$

\begin{tabular}{|c|c|c|c|}
\hline Entry & Alkene $(2, \mathrm{R})^{a}$ & Product (4) & $\begin{array}{c}\text { Isolated yield } \\
(\%) \text { of } 4\end{array}$ \\
\hline 1 & 2a (COOMe) & $4 a$ & $92(98)$ \\
\hline \multirow[t]{2}{*}{2} & & & $33(37)$ \\
\hline & (2h) & (4k) & \\
\hline
\end{tabular}

al.2 equiv. of olefin was used. "Tsolated yields. GC yield of 4 given in the parentheses. (entry 7).

As already stated, the enhanced reactivity of acrylic ester with MW reaction can be also explained by the pronounced dipole-polarized transition state of $7 \mathfrak{c}$ due to the formation of a stable 5-membered metallacyclic complex through the carbonyl coordination to the rhodium metal. To confirm this hypothesis, one carbon elongated olefin, $\mathbf{2 h}$, was applied for MW-assisted orthoalkylation of 1a, and only a $33 \%$ isolated yield of corresponding orthoalkylated product $4 \mathbf{k}$ was obtained, differently from $92 \%$ yield of $4 a$ with 2 a under the identical reaction conditions (Table 4, entries 1 and 2). This result implies that methy] 3-butenoate (2h) acts as a common non-functionalized olefin such as $t$-butylethylene (2c) since a dipole-polarized intemmediate $7 \mathbf{d}$ is hardly formed because of its unstable nature of six-membered metallacyclic intemediate.

In conclusion, MW-assisted ontho-alkylation of aromatic benzylimine has been successfully achieved with olefins bearing carboxylic acid derivatives. The ortho-alkylation of aromatic ketimine with these olefins showed enhanced rate acceleration effect compared with the conventional thermal reaction, probably due to the specific $\mathrm{MW}$ effect. The reason for this effect must come from the involvement of $\mathrm{C}-\mathrm{O}$ dipole-polarized intermediate of a stable 5-membered metallacycle through the coordination of the carbonyl group to the metal center. The reaction is environmentally benign since it can be carried out with dramatically short reaction time with very high yields and solventless conditions. Further applications of these ortho-alkylation reactions with functionalized olefins are under study.

\section{Experimental Section}

General. Microwave reaction was performed using a single-mode microwave reactor (CEM Discover). The microwave power can be modulated from 15 to $300 \mathrm{~W}$ $(2,450 \mathrm{MHz})$ and the high powered microwave can be obtained by blowing air to the reaction vessel to maintain the temperature. The reaction temperature, pressure, and microwave power were monitored using a computer controlled CEM-Discover focused synthesis system. The thick-walled 10-mL Pyrex reaction vessel with Teflon septa was used as a reaction vessel. In order to compare microwave irradiation with conventional heating, the reactions were performed in the same reaction vessel under similar experimental conditions (weight of reactants and temperature) using a thermostated oil bath with similar profiles of increasing temperature. The ${ }^{1} \mathrm{H}$ NMR and ${ }^{13} \mathrm{C}$ NMR spectra were recorded on Bruker Advance/DPX $250\left(250 \mathrm{MHz}{ }^{\mathrm{H}} \mathrm{H}, 62.9\right.$ $\mathrm{MHz}{ }^{13} \mathrm{C} \mathrm{NMR}$ ) spectrometers with chemical shifts reported relative to residual deuterated solvent peaks. ${ }^{1} \mathrm{H}$ NMR spectra were referenced to tetramethylsilane $(0.00 \mathrm{ppm})$ as an internal standard. ${ }^{13} \mathrm{C}$ NMR spectra were referenced to the residual $\mathrm{CDCl}_{3}(77.26 \mathrm{ppm})$. Gas chromatographic analyses were performed on a Donam DS 6200 instrument with FID detector and a Hewlett Packard HP-5 capillary column. Low- resolution mass spectra were measured on a 
Hewlett-Packard HP G1800A GCD system equipped with a Hewlett Packard HP-5 capillary column. Infrared spectra were obtained on a Nicolet Impact 400 spectrometer. High-resolution mass spectrometry was performed by the National Center for Inter-University Facilities, Seoul National University (Seoul 151-742, Korea). Flash column chromatography was performed using E. Merck 230-400 mesh silica gel. Column chromatography was monitored by analytical thin layer chromatography (TLC) that was performed on precoated silica gel plates with fluorescent indicator UV254 (layer thickness: $0.25 \mathrm{~mm}$, silica gel 60, F-254, Merck).

Materials. Ketones and olefins used in the experiments were purchased from Aldrich Chemical Company and used as received without further purification unless otherwise stated. $\left(\mathrm{PPh}_{3}\right)_{3} \mathrm{RhCl}$ (Wilkinson's complex) was prepared as described in the literature. ${ }^{8}$ All aromatic ketimines are known compounds and, data extracted from them were consistent with that reported in the literature. ${ }^{4.9}$ All products were previously characterized and known compounds in the literature except $\mathbf{4 d}, \mathbf{4 e}, \mathbf{4 f}, \mathbf{4 g}$, and $\mathbf{4 h}$.

Experimental procedure for ortho-alkylation. A typical procedure (Table 1): A thick-wall Pyrex tube $(10 \mathrm{~mL})$ was charged with aromatic ketimine $(1,0.3 \mathrm{mmol})$, olefin (2, $0.36 \mathrm{mmol})$, and $\left(\mathrm{PPh}_{3}\right)_{3} \mathrm{RhCl}(3,0.015 \mathrm{mmol})$. The reaction vessel was capped with Teflon septa and installed in a CEMDiscover Microwave reactor. The reaction was carried out with an intemal magnetic stirring bar for $10 \mathrm{~min}$ to ensure homogeneous conditions at $150{ }^{\circ} \mathrm{C}$ under microwave irradiation. For the conventional heating, the vessel was placed into the $150^{\circ} \mathrm{C}$-preheated oil bath. The reaction time was $10 \mathrm{~min}$ with an additional ramp time $(60 \mathrm{sec})$. After cooling to room temperature, the reaction mixture was hydrolyzed with $1 \mathrm{~N} \mathrm{HCl}$ for $12 \mathrm{~h}$. The organic layer was neutralized with aqueous $\mathrm{NaHCO}_{3}$, and the solution extracted with $\mathrm{CH}_{2} \mathrm{Cl}_{2}$ and $\mathrm{EtOAc}$, and dried over anhydrous $\mathrm{MgSO}_{4}$, filtered, and concentrated. The product 4 was purified by column chromatography ( $n$-hexane:EtOAc $=$ 2:5) on silica gel.

3-(2-Acetyl-5-methoxyphenyl)- $N, N$-dimethyl propionamide (4d). 'H NMR (250 MHz; $\left.\mathrm{CDCl}_{3}\right) \delta 7.78$ (d, $J=8.6$, $1 \mathrm{H}), 6.87-6.78(\mathrm{~m}, 2 \mathrm{H}), 3.84(\mathrm{~s}, 3 \mathrm{H}), 3.18(\mathrm{t}, J=7.5,2 \mathrm{H})$, $3.01(\mathrm{~s}, 3 \mathrm{H}), 2.94(\mathrm{~s}, 3 \mathrm{H}), 2.66(\mathrm{t}, J=7.9,2 \mathrm{H}), 2.56(\mathrm{~s}, 3 \mathrm{H})$; ${ }^{13} \mathrm{C} \mathrm{NMR}\left(62.9 \mathrm{MHz} ; \mathrm{CDCl}_{3}\right) \delta 199.7(\mathrm{CO}), 172.8(\mathrm{CON})$, $162.3,145.6,132.9,129.8,117.1,111.8,55.5,37.4,35.6$, $35.5,31.4,29.3$. IR (neat) $v_{\max } / \mathrm{cm}^{-1} 2939,1673,1644$, $1602,1567,1495,1455,1416,1356,1321,1293,1248$, $1142,1068,1033,965,813,724$. HR-MS (EI) calcd. for $\mathrm{C}_{14} \mathrm{H}_{19} \mathrm{NO}_{3}\left(\mathrm{M}^{+}\right) 249.1365$, found 249.1367. MS (EI, $70 \mathrm{eV}$ ) $m / z 249\left(\mathrm{M}^{+}, 18\right), 231(11), 207(35), 177(33), 163(78), 135$ (13), $91(11), 77(10), 72(25)$.

3-(2-Acetyl-5-trifluoromethyl-phenyl)- $N, N$-dimethyl propionamide (4e). 'H NMR (250 $\left.\mathrm{MHz}^{-} \mathrm{CDCl}_{3}\right) \delta 7.74(\mathrm{~d}$, $J=8.0,1 \mathrm{H}), 7.60-7.53(\mathrm{~m}, 2 \mathrm{H}), 3.13(\mathrm{t}, J=7.2,2 \mathrm{H}), 2.97$ (s, $3 \mathrm{H}), 2.94(\mathrm{~s}, 3 \mathrm{H}), 2.67(\mathrm{t}, J=7.4,2 \mathrm{H}), 2.62(\mathrm{~s}, 3 \mathrm{H}) ;{ }^{13} \mathrm{C}$ NMR $\left(62.9 \mathrm{MHz}, \mathrm{CDCl}_{3}\right) \delta 201.5(\mathrm{CO}), 171.7(\mathrm{CON})$, $142.0,141.3,128.8,128.3,128.2,123.1,123.0,37.1,35.3$, $35.1,29.9,29.8 ; \mathbb{R}$ (neat) $V_{\text {max }} / \mathrm{cm}^{-1} 2928,2097,1694$,
$1646,1499,1458,1412,1330,1251,1164,1152,1090,833$. HR-MS (EI) calcd. for $\mathrm{C}_{14} \mathrm{H}_{1} \mathrm{~F}_{3} \mathrm{NO}_{2}\left(\mathrm{M}^{+}\right) 287.1133$, found 287.1132. MS (EI, $70 \mathrm{eV}) m / z 287\left(\mathrm{M}^{+}, 31\right), 244(100), 215$ (28), $199(37), 177(14), 156(10), 151$ (16), $87(82), 72(49)$.

3-(2-Heptanoyl-phenyl)- $N, N$-dimethyl propionamide (4f). ${ }^{1} \mathrm{H}$ NMR (250 MHz, $\left.\mathrm{CDCl}_{3}\right) \delta 7.62(\mathrm{~d}, J=7.6,1 \mathrm{H})$, $7.40-7.27(\mathrm{~m}, 3 \mathrm{H}), 3.08(\mathrm{t}, J=7.3,2 \mathrm{H}), 2.95(\mathrm{~s}, 3 \mathrm{H}), 2.93(\mathrm{~s}$, $3 \mathrm{H}), 2.69(\mathrm{t}, J=7.8,2 \mathrm{H}), 1.71-1.66(\mathrm{~m}, 2 \mathrm{H}), 1.38-1.32(\mathrm{~m}$, $6 \mathrm{H}), 0.91-0.86(\mathrm{~m}, 3 \mathrm{H}) ;{ }^{13} \mathrm{C} \mathrm{NMR}\left(62.9 \mathrm{MHz}, \mathrm{CDCl}_{3}\right) \delta$ $205.2(\mathrm{CO}), 172.6(\mathrm{CON}), 141.2,138.7,131.7,131.3,128.3$, $126.2,41.9,37.2,35.9,35.5,31.7,30.3,29.0,24.4,22.6$, 14.1. IR (neat) $\gamma_{\mathrm{max}} / \mathrm{cm}^{-1} 2924,2851,1683,1651,1482$, $1392,1270,1135,753$. HR-MS (EI) calcd. for $\mathrm{C}_{18} \mathrm{H}_{27} \mathrm{NO}_{2}$ $\left(\mathrm{M}^{+}\right)$289.2042, found 289.2042. MS (EI, $70 \mathrm{eV}$ ) $\mathrm{m} / \mathrm{z} 289$ $\left(\mathrm{M}^{+}, 24\right), 232(49), 219(33), 202(61), 176(91), 149(27)$, $131(69), 117(15), 103(25), 87(13), 72$ (42).

3-(2-Acetyl-phenyl)-1-pyrrolidinyl propanone $(4 \mathrm{~g}) .{ }^{1} \mathrm{H}$ NMR (250 MHz, CDCl $) \delta 7.70-7.29(\mathrm{~m}, 4 \mathrm{H}), 3.45(\mathrm{t}, J=$ $6.6,2 \mathrm{H}), 3.36(\mathrm{t}, J=6.5,2 \mathrm{H}), 3.15(\mathrm{t}, J=7.8,2 \mathrm{H}), 2.62(\mathrm{t}, J$ $=8.3,2 \mathrm{H}), 2.59(\mathrm{~s}, 3 \mathrm{H}), 1.93-1.78(\mathrm{~m}, 4 \mathrm{H}) .{ }^{13} \mathrm{C} \mathrm{NMR}(62.9$ $\left.\mathrm{MHz}, \mathrm{CDCl}_{3}\right) \delta 202.4(\mathrm{CO}), 171.4(\mathrm{CON}), 142.2,138.0$, $131.9,129.5,128.8,126.3,46.8,45.8,37.1,30.3,29.9,26.3$, 24.6. IR (neat) $\gamma_{\text {nax }} / \mathrm{cm}^{-1} 2973,2868,1681,1635,1436$,

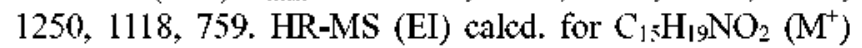
245.1416, found 245.1416. MS (EI, $70 \mathrm{eV}) \mathrm{m} / \mathrm{z} 245\left(\mathrm{M}^{+}\right.$, 54), $202(100), 133(40), 113(42), 98(29), 77(21), 70(50)$, $55(16)$.

3-(2-Acetyl-phenyl)- $N$-isopropyl propionamide (4h). ${ }^{1} \mathrm{H}$ NMR (250 MHz, $\left.\mathrm{CDCl}_{3}\right) \delta 7.75(\mathrm{~d}, J=8.5,1 \mathrm{H}), 7.44-7.29$ (m, 3H), 5.90-5.88 (br s, 1H), 3.11 (t, $J=7.8,2 \mathrm{H}), 2.61$ (s, $3 \mathrm{H}), 2.48(\mathrm{t}, J=8.0,2 \mathrm{H}), 1.19(\mathrm{~d}, J=6.6,3 \mathrm{H}), 1.11$ (d, $J=$ $6.6,3 \mathrm{H}) .{ }^{13} \mathrm{C} \mathrm{NMR}\left(62.9 \mathrm{MHz}, \mathrm{CDCl}_{3}\right) \delta 202.2(\mathrm{CO}), 171.9$ (CON), 141.9, 137.1, 132.2, 131.7, 130.1, 126.6, 41.4, 39.3, $31.4,29.8,23.0,22.4$. R (neat) $v_{\max } / \mathrm{cm}^{-1} 3298,2930,2097$, $1732,1678,1641,1546,1450,1413,1251,1071$ and 767. HR-MS (EI) caled. for $\mathrm{C}_{14} \mathrm{H}_{19} \mathrm{NO}_{2}\left(\mathrm{M}^{+}\right)$233.1416, found 233.1414. MS (EI, $70 \mathrm{eV}) \mathrm{m} / \mathrm{z} 233\left(\mathrm{M}^{+}, 20\right), 190(23), 175$ (16), $146(21), 131(31), 103(14), 77(9)$.

Acknowledgement. This work was supported by the Korea Research Foundation Grant funded by the Korean Government (MOEHRD) (KRF-2005-070-C00072) and CBMH. E.-A. J. acknowledges the fellowship of the BK21 program from the Ministry of Education and Human Resources Development and the Seoul Science Fellowship Program. We also thank Prof. André Loupy for his technical assistance and helpful discussion.

\section{References}

I. Dyker, G In Handbook of $\mathrm{C}-\mathrm{H}$ Transformations; Wiley-VCH: Weinheim (Germany), 2005; For recent reviews: (a) Kakiuchi, F; Chatani, N. Adv: Synth. Catal. 2003, 345, 1077-1 10l. (b) Ritleng, V.; Sirlins, C.; Pfeffer, M. Chem. Rev: 2002, 102, 1731-1769. (c) Dyker, G. Angew. Chem. Int. Ed. 1999, 38, 1698-1712. (c) Park, Y.-J.; Jun, C.-H. Bull. Korean Chem. Soc. 2005, 26, 871-877. (d) Cho, C.-S.; Kim, D.-Y.; Shim, S.-C. Bull. Korean Chem. Soc. 2005, 26, 802-804. 
2. (a) Kakiuchi, F.; Murai, S. In Activation of Unreactive Bonds and Organic Synthesis; Murai, S., Ed.; Springer: Berlin, German, 1999. (b) Murai, S.; Kakiuchi, F.; Sekine, S.; Tanaka, Y; Kamatani, A.; Sonoda, M.; Chatani, N. Noture 1993, 366, 529530. For Murai's ortho-alkylation: (a) Kakiuchi, F.; Sekine, S.; Tanaka, Y.; Kamatani, A.; Sonoda, M.; Chatani, N.; Murai, S. Bull. Chem. Soc. Jpn, 1995, 68, 62. (b) Murai, S.; Chatani, N.; Kakiuchi, F. Ptre Appl. Chem. 1997, 69, 589-594. (c) Sonoda, M.; Kakiuchi, F.; Chatani, N.; Murai, S. Bull. Chem. Soc. Jpn. 1997. 70, 3117. (d) Sonoda, M.; Kakiuchi, F.; Kamatani, A.; Chatani, N.; Murai, S. Chem. Lett, 1996, 109-110. (e) Kakiuchi, F.; Yamauchi, M.; Chatani, N.; Murai, S. Chem. Lett, 1996, 11 l-III.

3. (a) Jun, C.-H.; Moon, C. W; Hong, J.-B.; Lim, S.-G.; Chung, K.Y.; Kim, Y.-H. Chem. Etr, J. 2002, 8, 485-492. (b) Jun, C.-H.; Hong, J.-B.; Kim. Y.-H.; Chung, K.-Y. Angew. Chent, Int. Ed. 2000, 39, 3440-3442. (c) Lim, S.-G.; Lee, J. H.; Moon, C. W,; Hong, J. B.; Jun, C.-H. Org. Lett. 2003, 5, 2759-2761.

4. Lim, S.-G; Ahn, J.-A.; Jun, C.-H. Org. Lett, 2004, 6, 4687-4690.
5. (a) Loupy, A. In Microwanes in Organic Synthesis, 2nd ed. Wiley-VCH: Weinheim (Gennany), 2006. (b) Kappe, C. O.; Stadler, A. In Microwaves in Organic and Medicinal Chenistry" Wiley-VCH: 2005. (c) Kim, Y.-H.; Kim, Y.-J.; Chang, S.-Y.; Kim, B.-T.; Heo, J.-N. Bull. Korean Chem. Soc. 2007, 28, 777-782.

6. (a) Perreux, L.; Loupy, A. Tetrahedron 2001, 57, 9199-9223. (b) reference $5 \mathrm{a}, \mathrm{p}$ 134-218.

7. (a) Ahn, J.-A.; Chang, D.-H.; Park, Y. J.; Yon, Y. R.; Loupy, A.; Jun, C.-H. Act. Symth. Catal. 2006, 348, 55-58. (b) Loupy, A.; Chatti, S.; Delamare, S.; Lee, D.-Y.; Chung, J.-H.; Jun, C.-H. J. Chem. Soc., Perkin Trans, I 2002, 10, I280-1285. (c) Jun, C.-H,; Chung, J.-H.; Lee, D.-Y; Loupy, A.; Chatti, S. Tetrahedron Lett. 2001, 42, 4803-4805.

8. Osborn, J. A.; Wilkinson, G. In Reagents for Transition Metal Contplex and Organtontetallic Syntheses; Angelici, R., Ed.; Wiley: New York, 1989; Vol. 28, pp 77-79.

9. Thalji, R. K.; Ellman, J. A.; Bergman, R. G. J. Am. Chem. Soc. 2004, 126, 7192-7193. 